UDC: 615.015.2:615.073:615.281

DOI: 10.15587/2519-4852.2018.122975

\title{
VERIFICATION OF DISSOLUTION TEST FOR DOXYCYCLINE HYCLATE IN CAPSULES TO IMPLEMENT INTO THE PHARMACOPOEIAL MONOGRAPH
}

\author{
(C)A. Dobrova, O. Golovchenko, V. Georgiyants
}

\begin{abstract}
Вивчення профілів розчинення є важливими в якості доповнення до дослідження біоеквівалентності, $і$ як різновид таких досліджень, як простий і недорогий метод. Тест «Розчинення» для капсул доксицикліну не описаний у ДФУ. Отже, відповідно до поточних вимог, було необхідно верифікувати методику, рекомендовану Американською Фармакопеєю та підтвердити те, щзо вона буде відтворена правильно в конкретній лабораторії для використання в наших подальших дослідженнях.

Метою нашого дослідження було перевірити аналітичну методику тест "Розчинення" для капсул доксіцикліну хіклату, рекомендований Американською Фармакопеєю.

Методи. Капсули доксицикліну хіклату 100 мг та ряд мінеральних вод були взяті в якості об'єктів дослідження. Для приготування порівняльних розчинів використовували стандартний зразок доксицикліну. Всі реактиви та пробні зразки відповідають вимогам ДФУ. Експериментальні дані одержували одночасно за стандартною процедурою. 3 иією метою було вивчено 9 точок у межах 55-135\% з кроком $10 \%$. Отримані результати оброблялися статистично відповідно до вимог ДФУ.

Результати. Проведений прогноз показав, щчо повна невизначеність результатів методики становить 1,04\%, щзо не перевищує критичного значення (3,0\%). Для визначення специффічності досліджували вплив плацебо. Розрахунок показав, щзо загальний вплив плацебо на сумарне поглинання препарату є незначним $(0,51 \% \leq 0,96 \%)$. Крім того, метод лінійний у діапазоні конщентрацій від $55 \%$ до $135 \%$. Систематична похибка результатів задовольняє рекомендованим критеріям.
\end{abstract}

Висновки. Аналіз модельних сумішей доксииикліну хіклату показав правильність досліджуваного методу Ключові слова: капсули доксицикліну хіклату, верифікація, імплементачія, тест розчинення, лінійність, критерії прийнятності, правильність методики

\section{Introduction}

Nowadays, Ukraine continues to update national quality standards to European ones. The State Pharmacopoeia of Ukraine (SPhU) is harmonized with the European Pharmacopoeia, yet the European Pharmacopoeia does not produce monographs for the dosage forms. That's why, today, research is actively carried out to develop new procedures or to verify uniform procedures of standardization and quality control for the dosage forms, which are generics.

2. Formulation of the problem in a general way, the relevance of the theme and its connection with important scientific and practical issues

Growth of microorganism resistance to the most commonly used antibiotics necessitates the return to some classical antibiotics that are susceptible to certain groups of pathogens [1]. So widely known antibiotic doxycycline is relevant in the treatment sexually transmitted infections, chlamydia and mixed etiology, pelvic inflammatory diseases and lower respiratory tract infections, and also can successfully solve the problem of atypical pathogens $[1,2]$. In addition, doxycycline is effective in the treatment of inflammatory diseases of the joints, such as autoimmune arthritis, osteoarthritis and gonococcal arthritis. Studies have shown anti-inflammatory and immunomodulatory activity of doxycycline. When taken with glucosamine hydrochloride, it has a pronounced effect on the parameters of the cartilage and bone tissue metabolism against the background of the development of autoimmune arthritis and leads to inhibition of immune-inflammatory processes in the connective tissue of animals [3].
Studies have shown that doxycycline is effective in treating inflammatory skin lesions associated with acne, rosacea (chronic skin dermatosis), bullous and other types of dermatosis; scleroderma, sarcoidosis and sarcoma and even cancer. The mechanism of action is not clear to the end though. The effect may be caused by a partial anti-inflammatory, antiangiogenic and immunomodulatory action of antibiotics [4].

3. Analysis of recent studies and publications in which a solution of the problem is found and which draws on the author

State Pharmacopoeia of Ukraine does not offer a monograph for dosage forms of doxycycline [5]. United States Pharmacopoeia (USP) recommends analyzing doxycycline capsules by liquid chromatography [6]. Different colour reactions with various reagents is using for express analysis [7]. Chemical and physicochemical methods such as UV spectrophotometry with different variations can be used as fast, simple and sensitive procedure of analysis [8].

The correspondence between the efficacy and safety of the drugs ensures their interchangeability in clinical practice; this can be confirmed by comparative studies "in vivo", as well as "in vitro" studies [9]. An example of such a test is a comparative dissolution kinetics test for investigating the behavior of medicinal preparations "in vitro". The "Dissolution" test is recommended by the world pharmacopoeias for the determining the release kinetics of the solid dosage forms and is necessary for their pharmaceutical development. The study of dissolution profiles is important both as a supplement to bioequivalence research and 
as variations to such studies and it is also is inexpensive and easy to perform [10].

\section{Allocation of unsolved parts of the general problem, which is dedicated to the article}

According to the current requirements, analytical method should be validated before using in the analysis of medicinal products [5]. Pharmacopoeial procedures can be used in quality control of medicines only after confirmation that a particular composition does not lead to unacceptable changes of the correctness, linearity or precision of the method [11].For the procedures and tests, which were validated and included in the pharmacopoeia, only verification is required in order to confirm basing on experimental data that in this laboratory pharmacopoeias procedure or test will be reproduced correctly.

Since, the method of the dissolution test for doxycycline capsules is not outlined in the State Pharmacopoeia of Ukraine. Considering mentioned above, it was necessary to verify the method recommended by the US Pharmacopeia to use it in our further studies.

\section{Formulation of goals (tasks) of the article}

To achieve the goals of our research, such tasks were formulated:

1. To verify the "Dissolution" test for the capsules of doxycycline hyclate, recommended by the US Pharmacopeia.

2. To determine main validation characteristics for the selected procedure using the permissibility criteria.

\section{Statement of the basic material of the study (methods and objects) with the justification of the results}

The study objects were capsules of doxycycline $100 \mathrm{mg}$ (series 030117/02/20, manufactured by PJSC SIC “Borshchahivskiy CPP”, Ukraine). A standard sample of doxycycline (series YD140301067, manufactured by Yangzhou Liberty Pharmaceutical Co., Ltd, China) was used for preparation the comparison solutions. The analytical weights of Mettler Toledo AB-204 / A, Spectrophotometer "Specord200" (Germany) and grade A glassware were used during the study. All reagents and test specimens meet the requirements of the SPhU [5].

The studied method of the "Dissolution" test for capsules of doxycycline hyclate was taken from the US Pharmacopoeia [6].

Method of analysis: the study was conducted in a medium of $900 \mathrm{ml}$ purified water. As equipment for testing apparatus 2 (paddle) was used with a $75 \mathrm{rpm}$ speed of rotation. Study time $30 \mathrm{~min}$. The analysis of the sample was carried out by the method of absorption spectrophotometry in the UV region of the spectrum, using the standard method. The absorbance of the test solution and the comparison solution was measured at a wavelength of $276 \mathrm{~nm}$ relatively to the compensation solution. Not less than $80 \%$ of the nominal content of doxycycline hyclate should be dissolved within 30 minutes [6].

The experimental data were obtained at the same time in a standardized procedure. For this purpose, 9 points were studied within the range $55-135 \%$ with a step of $10 \%$. At the same time, three measurements of each concentration were performed simultaneously. The obtained results were processed statistically in accordance with the requirements of the SPhU [12].

To confirm the possibility of using the dissolution test procedure for doxycycline hyclate capsules, results obtained during the experimental study were compared with the analytical characteristics of the dissolution test such as: accuracy; precision: repeatability, intermediate precision; specificity; linearity. To confirm the correctness of the procedure, a prediction of complete uncertainty of the analytical procedure was also conducted [13].

The total uncertainty of the analysis $\Delta_{\mathrm{AS}}$, the uncertainty from sampling $\left(\Delta_{\mathrm{SP}}\right)$ and the uncertainty of the final analytical operation $\left(\Delta_{\mathrm{FAO}}\right)$ were defined. The investigated solution and the comparison solution, as well as at least three parallel measurements of the absorbance with the cuvette removal were taken into account:

$$
\begin{aligned}
& \Delta_{A S}=\sqrt{\Delta_{S P}^{2}+\Delta_{F A O}^{2}}=\sqrt{0.77^{2}+0.70^{2}}= \\
& =1.04 \% \leq \max \Delta_{A S}=3.0 \% .
\end{aligned}
$$

Thus, for the tested method, the uncertainty of the analysis $\left(\Delta_{\mathrm{AS}}\right)$ is 1.04 , which does not exceed the critical criteria $(3.0 \%)$, that means, it is non-significant.

To determine the specificity, the influence of placebo was studied. To do this, the solution of a medicine $\left(\mathrm{A}_{\mathrm{st}}\right)$ and a solution of a placebo $\left(\mathrm{A}_{\text {plac }}\right)$ - a mixture of lactose monohydrate and calcium stearate were prepared. After that a parallel measurement of the placebo solution absorbance $\left(\mathrm{A}_{\text {plac }}\right)$ and the comparison solution absorbance $\left(\mathrm{A}_{\mathrm{st}}\right)$ was performed, making three measurements with the cuvette removal. The following results were obtained: $\mathrm{A}_{\text {plac }}=0.0034 ; \mathrm{A}_{\mathrm{st}}=0.648$. Total absorption of the solution is

$$
\delta_{\text {esc }}=\frac{100 \cdot 0.0034}{0.648}=0.51 \% \leq 0.32 \cdot 3.0=0.96
$$

Since the obtained systematic error value meets the criterion for the analytical procedure $(0.51 \% \leq 0.96 \%)$, this procedure can be considered as specific [14].

The study of the linear dependence of the absorbance on concentration was performed on 9 model mixtures in the range of the method application, as recommended by the $\mathrm{SPhU}$, for assay of the active substance in the dosage forms in the range from $55 \%$ to $135 \%$ with a step of $10 \%$ [12].

In the Fig. 1 we can see a graph of the dependence of absorbance on the concentration of doxycycline hyclate in normalized coordinates. The calculation of linear dependency parameters for doxycycline was performed using the least squares method.

The angular slope $b$, the Y-intercept $a$, the residual standard deviation (residual dispersion), the dispersion of the constants $\mathrm{b}$ and $\mathrm{a}$, the standard deviations $\mathrm{s}_{\mathrm{b}}$ and $\mathrm{s}_{\mathrm{a}}$, the correlation coefficient $r$, the linear correlation coefficient and the standard deviation $\mathrm{s}_{\mathrm{Y}}$ were calculated. The results of these calculations are given in Table 1, 2 . 


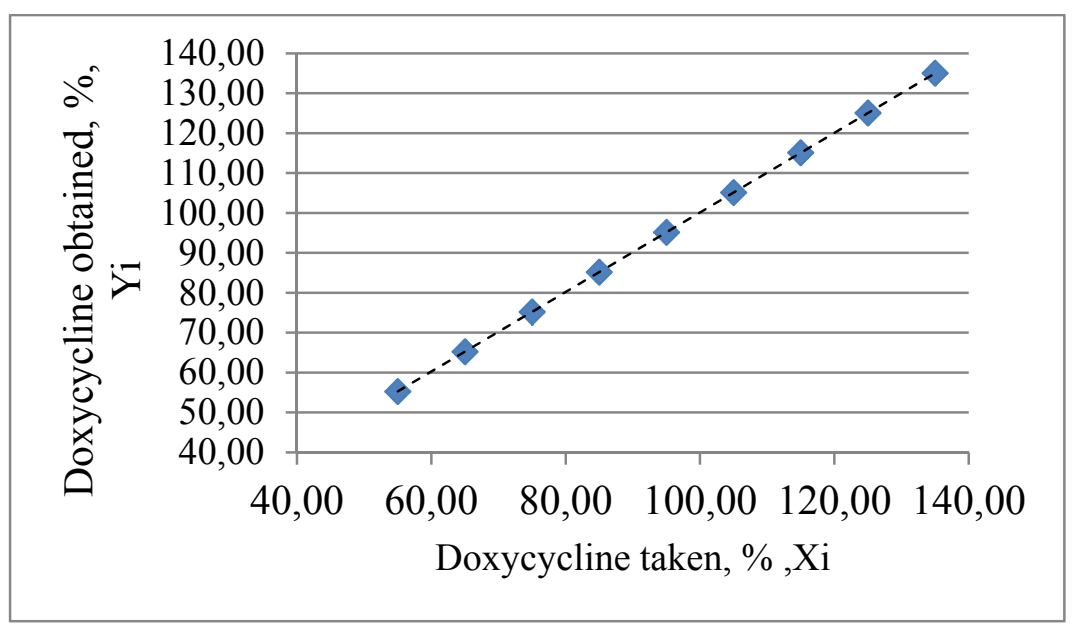

Fig. 1. The graph of linear dependence of absorbance on doxycycline solution concentration

Accuracy was assessed by two criteria: criterion of statistical non-significance and practical non-significance criterion.

According to the criterion of statistical nonsignificance the systematic component of uncertainty $(\delta)$ can be calculated as a subtraction of $100 \%$ from the average ratio «found / entered» $(\bar{Z})$.The systematic error statistically does not differ from zero, if the deviation $\bar{Z}$ from $100 \%$ does not exceed its confidence interval [12]:

$$
\delta \%=|\bar{Z}-100| \leq \frac{\Delta_{Z}}{\sqrt{n}} ; \delta \%=0.22 \leq 0.37,
$$

where $\Delta_{Z}$ - confidence interval; $\mathrm{n}$ - amount of samples.

Results of the study of linear dependence on the doxycycline hyclate model mixture

\begin{tabular}{|c|c|c|c|c|}
\hline № of model solution & Entered, $X_{i}(\%)$ & $\begin{array}{c}\text { Absorbance, } A_{i} \\
\left(\mathrm{~A}_{\mathrm{st}}=0,6820\right)\end{array}$ & Found, $Y_{i}=\frac{A_{i}}{A_{s t}} \cdot 100$ & $Y_{i}=b \cdot X_{i}+a$ \\
\hline 1. & 55.00 & 0.3803 & 55.67 & 55.28 \\
\hline 2. & 65.00 & 0.4403 & 64.45 & 65.25 \\
\hline 3. & 75.00 & 0.5150 & 75.38 & 75.22 \\
\hline 4. & 85.00 & 0.5913 & 86.55 & 85.19 \\
\hline 5. & 95.00 & 0.6503 & 95.18 & 95.16 \\
\hline 6. & 105.00 & 0.7073 & 103.53 & 105.13 \\
\hline 7. & 115.00 & 0.7867 & 115.14 & 115.10 \\
\hline 8. & 125.00 & 0.8507 & 124.50 & 125.08 \\
\hline 9. & 135.00 & 0.9297 & 136.07 & 135.05 \\
\hline \multicolumn{4}{|c|}{ Average, \% } & 95.16 \\
\hline \multicolumn{4}{|c|}{ Slope, $b$} & 0.9971 \\
\hline \multicolumn{4}{|c|}{ Standart deviation of slope, $S_{b}$} & 0.0125 \\
\hline \multicolumn{4}{|c|}{ Y-intercept, $a$} & 0.4349 \\
\hline \multicolumn{4}{|c|}{ Standartdeviationofthe Y-intercept, $S_{a}$} & 1.2351 \\
\hline \multicolumn{4}{|c|}{ Residual standard deviation, $S_{o}$} & 0.9718 \\
\hline \multicolumn{4}{|c|}{ Linear correlation coefficient, $r$} & 0.9994 \\
\hline \multicolumn{4}{|c|}{ Standard deviation, $s_{Y}$} & 27.39 \\
\hline \multicolumn{4}{|c|}{ Criterion of linear correlation coefficient, $R_{c}$} & 0.9994 \\
\hline
\end{tabular}

The metrological characteristics of linear dependence for doxycycline hyclate

Table 2

\begin{tabular}{|c|c|c|c|}
\hline Parameter & Value & Criterion (for the range $55-135 \%$ ), $n=9$ & Conclusion \\
\hline$b$ & 0.9971 & - & - \\
\hline$S_{b}$ & 0.0125 & - & - \\
\hline$a$ & 0.4349 & $\begin{aligned}1) \leq 1.8946 \cdot S_{a}= & 3.11742) \text { if not executed } 1) \\
& \text { than } \leq 2.56\end{aligned}$ & Corresponds \\
\hline$S_{a}$ & 1.2351 & - & - \\
\hline$S_{o}$ & 0.9746 & $\frac{S_{0}}{b}=0.9746 \leq 1.5834$ & corresponds \\
\hline$r$ & 0.9994 & $\geq 0.9924$ & corresponds \\
\hline
\end{tabular}


Thus systematic error of investigated procedure, which equals 0.22 , does not exceed the criterion of statistical insignificance 0.37 and meets the requirements.

According to the practical non-significance criterion, if the ratio, mentioned above, is not satisfied, can be used the criterion of the non-significance of this systematic error in comparison with the maximal permissible uncertainty of the analysis [12]:

$$
\begin{aligned}
& \delta \%=|\bar{Z}-100| \leq 0.32 \cdot \Delta_{A S}=0.32 \cdot 3.0=0.96 ; \\
& \delta \%=0.22 \leq 0.96 .
\end{aligned}
$$

After analyzing the data obtained, we can conclude that the systematic error of the results satisfies the recommended criterion.

For the determination of precision we calculated the repeatability of the method. It refers to the use of analytical procedure within a laboratory over a short period of time by the same analyst using the same equipment [5]. The repeatability of the analytical procedure usually determined by the deviation, standard deviation, or relative standard deviation for a series of measurements [13].

Statistical characteristics the average value $\mathrm{Z}$ and the relative standard deviation were calculated. Their values are $100.22 \%$ and $1.0076 \%$, accordingly.

According to the requirements, the one sided confidence interval $\Delta \mathrm{Z}$ should not exceed the critical value of the uncertainty of the analysis $\Delta_{\mathrm{AS}}$ :

$$
\begin{aligned}
& \Delta_{Z}=s_{z}(\%) \cdot t(95 \%, \mathrm{n}-1) \leq \max \Delta_{\mathrm{AS}} ; \\
& \Delta_{Z}=1.0076 \cdot 1.8595=1.8736 \leq 3.0 .
\end{aligned}
$$

Experimental data, obtained during the study, satisfy the requirements - the confidence interval does not exceed the maximal permissible uncertainty [14].

The results obtained and calculated, as well as their

\begin{tabular}{|c|c|c|c|c|c|}
\hline № & Aliquot, ml & $\begin{array}{l}\text { Entered to nomi- } \\
\text { nal amount, } \\
(\mathrm{Xi}, \%)\end{array}$ & $\begin{array}{c}\text { Absorbance, } A_{i} \\
\quad\left(A_{s t}=0,682\right)\end{array}$ & $\begin{array}{l}\text { Obtained for the } \\
\text { nominal volume } \\
\qquad\left(\mathrm{Y}_{\mathrm{i}}, \%\right)\end{array}$ & $\begin{array}{l}\text { Obtained in } \% \text { to entered } \\
\qquad \mathrm{Z}_{i}=100 \cdot \frac{Y_{i}}{X_{i}}\end{array}$ \\
\hline 1 & 1.1 & 55.0 & 0.3803 & 55.67 & 101.21 \\
\hline 2 & 1.3 & 65.0 & 0.4403 & 64.45 & 99.15 \\
\hline 3 & 1.5 & 75.0 & 0.5150 & 75.38 & 100.50 \\
\hline 4 & 1.7 & 85.0 & 0.5913 & 86.55 & 101.82 \\
\hline 5 & 1.9 & 95.0 & 0.6503 & 95.18 & 100.19 \\
\hline 6 & 2.1 & 105.0 & 0.7073 & 103.53 & 98.60 \\
\hline 7 & 2.3 & 115.0 & 0.7867 & 115.14 & 100.12 \\
\hline 8 & 2.5 & 125.0 & 0.8507 & 124.50 & 99.60 \\
\hline 9 & 2.7 & 135.0 & 0.9297 & 136.07 & 100.79 \\
\hline \multicolumn{5}{|c|}{ Average value, $\mathrm{Z}, \%$} & 100.22 \\
\hline \multicolumn{5}{|c|}{ Relative standard deviation, $\mathrm{S}_{\mathrm{Z}}, \%$} & 1.0076 \\
\hline \multicolumn{5}{|c|}{ Relative confidence interval, $\Delta_{\mathrm{z}}, \%=\mathrm{t}(95 \%, \mathrm{n}-1) \cdot \mathrm{Sz}$} & 1.8737 \\
\hline \multicolumn{5}{|c|}{ Critical values of the analysis uncertainty, $\Delta_{\mathrm{AS}}, \%$} & 3.0 \\
\hline \multicolumn{5}{|c|}{ Systematic error, $\delta, \%$} & 0.22 \\
\hline \multicolumn{5}{|c|}{ Criterion of the statistical uncertainty of the systematic error, $\delta, \%$} & 0.62 \\
\hline \multicolumn{5}{|c|}{ Criterion of the practical uncertainty of the systematic error, $\delta, \%$} & 0.96 \\
\hline \multicolumn{5}{|c|}{ Overall conclusion about the method } & correct \\
\hline
\end{tabular}
statistical characteristics, are presented in the Table 3.

Table 3

Results of doxycycline hyclate model mixtures analysis

During the analysis of the doxycycline hyclate model mixtures using the method of the dissolution test proposed by the US Pharmacopeia, its correctness was proved in the conditions of the domestic laboratory. The prediction of complete uncertainty of the proposed method meets the eligibility criteria, which confirms the possibility of this method application.

\section{Findings from the research and prospects of}

\section{further development of this area}

1. The verification of the "Dissolution" test procedure for the capsules of doxycycline hyclate, recommended by the US Pharmacopeia, was carried out, for which the validation characteristics for the selected methodic using the permissibility criteria were determined.

2. The conducted prediction showed that the total uncertainty of the results of the method is $1.04 \%$, which does not exceed the critical value $(3.0 \%)$. To determine the specificity, the effect of placebo $\left(\delta_{e s c}\right)$ was investigated. The calculation showed that the overall effect of placebo on the total absorption of the drug is nonsignificant $(0.51 \% \leq 0.96 \%)$.

Also, the method is linear in the range of concentrations from $55 \%$ to $135 \%$. The systematic error of the results meets the recommended criteria.

3 . The analysis of model mixtures of doxycycline hyclate showed the correctness of the investigated procedure.

4. The verified procedure for the "Dissolution" test for doxycycline hyclate capsules can be implemented into the State Pharmacopoeia of Ukraine, practice of laboratories for medicinal products quality control and used in our further research of dissolution kinetics. 


\section{References}

1. Kozlov R. S., Holub A. V. Mesto doksitsyklina v sovremennoi klinicheskoi praktike // Meditsinskii sovet. 2014. Vol. 9. P. $118-124$.

2. Sexually Transmitted Diseases Treatment Guidelines, 2010. Vol. 59. Centers for Disease Control and Prevention. MMWR. 2010. 110 p.

3. Study of anti-inflammatory activity of compounds on the basis of doxycycline hydrochloride and glucosamine hydrochloride / Zupanets I. A., Tkachenko K. M., Otrishko I. A., Grintsov Ye. F. // Ukrayinskii zhurnal klinichnoy ta laboratornoy medycyny. 2014. Vol. 9, Issue 3. P. 37-40.

4. Sapadin A. N., Fleischmajer R. Tetracyclines: Nonantibiotic properties and their clinical implications // Journal of the American Academy of Dermatology. 2006. Vol. 54, Issue 2. P. 258-265. doi: 10.1016/j.jaad.2005.10.004

5. State Pharmacopoeia of Ukraine. Vol. 1. Kharkiv: Ukrainian Scientific Pharmacopoeial Centre for Quality of Medicines, 2014. 724 p.

6. United States Pharmacopeia 39. Vol. 1. Rockville: USP Convention Inc., 2016. URL: http://www.usp.org/sites/default/ files/usp/document/our-work/biologics/USPNF810G-GC-1132-2017-01.pdf

7. Pharmaseutical analysis / Bezugly P. O., Georgiyants V. A., Grytsenko I. S. et. al.; Georgiyants V. A. ed. Kharkiv: Golden pages, 2013. $552 \mathrm{p}$.

8. Kumar A., Nanda S., Chomwal R. Spectrophotometric methods for determination of doxycycline in Tablet formulation // International Journal of ChemTech Research. 2010. Vol. 2, Issue 1. P. 599-602.

9. Test «Rastvorenie» i sovremennye podhody k ocenke ehkvivalentnosti lekarstvennyh preparatov (obzor) / Smekhova I. E., Perova Yu. M., Kondratyeva I. A., Rodygina A. N., Tureckova N. N. // Drug development and registration. 2013. Vol. 1, Issue 2. P. 50-61.

10. Grebenkin D. Yu., Stanishevskiy Ya. M., Shohin I. E. Sovremennye podhody k provedeniyu sravnitelnogo testa kinetyki rastvorenia (obzor). Drug development and registration. 2016. Vol. 1, Issue 14. P. 166-171.

11. Gryzodub A. I. Standartnye procedury validacii metodik kontrolya kachestva lekarstvennyh sredstv. Farmakom. 2006. Vol. 1, Issue 2. P. 35-44.

12. Guidance on the validation of drug analysis procedures / Bagirova V. L., Gryzodub A. I., Chibilyaev T. H. et. al. Moscow: Farmatsevtycheskaia promishlennost. 2007. 58 p.

13. Analytical method validation and instrument performance verification / Chan C. C., Lam H., Lee Y. C., Zhang X.-M. Eds. Hoboken: JohnWiley\&Sons, 2004. P. 11-51. doi: 10.1002/0471463728

14. Gryzodub A. I. Validaciya spektrofotometricheskih metodik kolichestvennogo analiza lekarstvennyh sredstv v sootvetstvii s trebovaniyami GFU. Farmakom. 2002. Vol. 3. P. 42-50.

Дата надходження рукопису 24.01.2018

Anna Dobrova, Postgraduate student, Department of Pharmaceutical Chemistry, National University of Pharmacy, Pushkinska str., 53, Kharkiv, Ukraine, 61002,

E-mail: anna.dobrova08@gmail.com

Olga Golovchenko, PhD, Associate professor, Department of Pharmaceutical Chemistry, National University of Pharmacy, Pushkinska str., 53, Kharkiv, Ukraine, 61002

E-mail: golyas26@ukr.net

Victoria Georgiyants, Doctor of Pharmaceutical Sciences, Professor, Head of Department, Department of Pharmaceutical Chemistry, National University of Pharmacy, Pushkinska str., 53, Kharkiv, Ukraine, 61002

E-mail: vgeor@ukr.net 